\title{
Using cysteine/cystine to overcome oxidative stress in goat oocytes and embryos cultured in vitro
}

\author{
ZHENGRONG ZHOU $^{1,2^{*}}$, RUO-XIN JIA ${ }^{1 *}$, GUOMIN ZHANG $^{1}$, YONGJIE WAN ${ }^{1}$, YANLI ZHANG ${ }^{1}$, \\ YIXUAN FAN $^{1}$, ZIYU WANG ${ }^{1}$, PAN HUANG ${ }^{2}$ and FENG WANG ${ }^{1}$ \\ ${ }^{1}$ Jiangsu Livestock Embryo Engineering Laboratory, College of Animal Science and Technology, \\ Nanjing Agricultural University, Nanjing, Jiangsu 210095; ${ }^{2}$ Department of Histology and Embryology, \\ School of Medicine, Jiangsu University, Zhenjiang, Jiangsu 212013, P.R. China
}

Received March 30, 2015; Accepted February 19, 2016

DOI: $10.3892 / \mathrm{mmr} .2016 .5395$

\begin{abstract}
Assisted reproductive techniques expose gametes to excessive concentrations of reactive oxygen species. The present study aimed to evaluate the effects of oxidative stress on apoptosis in goat oocytes and embryonic development. The results demonstrated that the addition of $100 \mu \mathrm{M}$ hydrogen peroxide $\left(\mathrm{H}_{2} \mathrm{O}_{2}\right)$ into media produces an oxidative environment during oocyte maturation. The number of cumulus cells positive for terminal deoxynucleotidyl transferase UTP nick end labeling, and the activity of caspase 3 in mature oocytes were increased, compared with the control group $(\mathrm{P}<0.05)$. In addition, the expression levels of mitochondrial regulators, including peroxisome proliferator-activated receptor $\gamma$ coactivator-1 $\alpha$ (PGC-1 $\alpha$ ) and nuclear respiratory factor-1 (NRF-1) were increased in the oxidative oocytes, compared with those in the control group $(\mathrm{P}<0.05)$. The ratio of the proapoptotic gene, B cell lymphoma (Bcl-2)-associated X pr otein (BAX), to the anti-apoptotic gene, BCL-2, was higher in the $\mathrm{H}_{2} \mathrm{O}_{2}$ group, compared with the control group $(\mathrm{P}<0.05)$. To overcome oxidative stress in oocytes and embryos cultured in vitro, $200 \mu \mathrm{M}$ cysteine and $200 \mu \mathrm{M}$ cystine were added to the media, thereby increasing the concentration of intracellular glutathione (GSH) and assisting in maintaining the redox state of the cells. In conclusion, cysteine and cystine reduced the oxygen tension caused by $\mathrm{H}_{2} \mathrm{O}_{2}$, thereby providing a novel strategy for optimizing in vitro embryonic development systems.
\end{abstract}

Correspondence to: Mr. Yongjie Wan, Jiangsu Livestock Embryo Engineering Laboratory, College of Animal Science and Technology, Nanjing Agricultural University, Weigang 1, Nanjing, Jiangsu 210095, P.R. China

E-mail: 1hswan@126.com

*Contributed equally

Key words: cysteine and cystine, oocyte, in vitro, oxidative stress

\section{Introduction}

Mammalian oocytes are exposed to oxidative conditions (1). The oxidative modification of cell components caused by the increased production of reactive oxygen species (ROS) (2) compromises membrane integrity, and causes structural and functional changes in proteins, as well as damage to nucleic acids (3). ROS accelerate oocyte aging, lower oocyte quality, and induce apoptosis in oocytes and early embryonic cells (3). Therefore, increased ROS production negatively affects cell function and contributes significantly to several diseases, including those which damage reproduction and fertility (4). Accumulating evidence has demonstrated that oocytes are major sources of ROS, as they use oxygen to produce energy through mitochondrial oxidative phosphorylation (5). ROS production is higher during oocyte in vitro maturation (IVM) than during in vivo maturation (5). The major $\mathrm{ROS}, \mathrm{H}_{2} \mathrm{O}_{2}$, is produced intracellularly during several pathophysiologic processes, and causes oxidative damage. Exposure to exogenous $\mathrm{H}_{2} \mathrm{O}_{2}(25-300 \mu \mathrm{M})$ reportedly induces apoptosis in rat oocytes (1) and mouse zygotes (6). However, whether direct $\mathrm{H}_{2} \mathrm{O}_{2}$ exposure induces apoptosis in goat oocytes cultured in vitro remains to be elucidated.

Evidence has shown that glutathione (GSH) is involved in maintaining cellular redox states. Thus, the GSH content of oocytes protects the zygote and early embryos from oxidative damage prior to genomic activation (7). The addition of cysteine to oocyte culture media has been shown to increase intracellular levels of GSH in buffaloes (8,9), pigs (10) and goats (11). However, the effects of supplementation with a specific concentration of cysteine depend on the dose, the species and the maturation medium (2). The cystine content of TCM-199 (83.2 mM), a widely used medium, is sufficient for oocyte IVM, although the mechanism underlying its antioxidative capacity remains to be elucidated (12). The balance between ROS production and antioxidant defense is critical to the function of granulosa cells and oocytes $(13,14)$. The oocyte environment has a marked effect on the outcomes of assisted reproductive technologies (15). Cysteine is unstable and readily oxidized into cystine in the medium; therefore, the addition of cysteine and cystine to the medium decreases levels of oxidative stress on oocytes cultured in vitro. 
The present study aimed to determine the effects of $\mathrm{H}_{2} \mathrm{O}_{2}$, with and without cysteine and cystine, on the apoptosis of mature goat oocytes cultured in vitro. The effects examined included DNA damage, caspase-3 activity, mitochondria regulators and the gene expression of $\mathrm{B}$ cell lymphoma-2-associated $\mathrm{X}$ protein (BAX). In addition, the intracellular concentration of GSH in oocytes and their subsequent parthenogenetic embryonic development capacities were determined.

\section{Materials and methods}

Reagents. The chemicals used to culture the oocytes and embryos in the present study were obtained from Sigma-Aldrich (St. Louis, MO, USA), whereas media (including, TCM199, FBS, formaldehyde and Triton X-100) were from Gibco; Thermo Fisher Scientific, Inc., (Waltham, MA, USA). The RNeasy ${ }^{\circledR}$ Micro kit (cat. no. 74004) was purchased from QIAGEN (Valencia, CA, USA). SYBR Premix Ex Taq (cat. no. DRR420A) and the PrimeScript RT reagent kit with gDNA Eraser (cat. no. DRR047S) were purchased from Takara Biotechnology Co., Ltd. (Dalian, China). The One-Step Terminal Deoxynucleotidyl Transferase UTP Nick End Labeling (TUNEL) apoptosis assay kit (cat. no. C1088), the GSH and GSSG assay kits (cat. no. S0053), and the Caspase 3 activity assay kit (cat. no. C1116) were purchased from Beyotime Institute of Biotechnology (Haimen, China). All other chemicals were obtained commercially and were of reagent grade. All experiments were performed in accordance with the Guidelines for the Care and Use of Animals of the College of Animal Science and Technology, Nanjing Agricultural University (Nanjing, China) (16).

Preparation of $\mathrm{H}_{2} \mathrm{O}_{2}$, cystine and cysteine working solutions. The working solutions of $\mathrm{H}_{2} \mathrm{O}_{2}$ (Sigma-Aldrich; cat. no. H3410), cystine (Sigma-Aldrich; cat. no. C7602) and cysteine (Sigma-Aldrich; cat. no. C5360) were prepared freshly prior to use. Briefly, $3.5 \mu \mathrm{l}$ of $30 \% \mathrm{H}_{2} \mathrm{O}_{2}$ was diluted in $1 \mathrm{ml}$ of IVM culture media ( $30 \mathrm{mM})$. Subsequently, 10 and $12 \mu \mathrm{l}$ of this solution were further diluted in $3 \mathrm{ml}$ of culture media (100 and $120 \mu \mathrm{M})$. The $100 \mu \mathrm{M} \mathrm{H}_{2} \mathrm{O}_{2}$ solution was diluted into further concentrations of 60 and $80 \mu \mathrm{M}$. The cysteine stock solution $(20 \mathrm{mM})$ and the cystine stock solution $(100 \mathrm{mM})$ were diluted in culture media to obtain final concentrations of 100,200 and $500 \mu \mathrm{M}$. Thus, four IVM culture conditions were used for the oocytes in the present study, as follows: i) control (IVM media without chemical agent), ii) $\mathrm{H}_{2} \mathrm{O}_{2}$ (IVM media with $\mathrm{H}_{2} \mathrm{O}_{2}$ ), iii) CC (IVM media with cystine and cysteine), and iv) $\mathrm{H}_{2} \mathrm{O}_{2}$ and $\mathrm{CC}$ (IVM media with $\mathrm{H}_{2} \mathrm{O}_{2}$ and $\mathrm{CC}$ ).

Oocyte collection. Goat ovaries were collected from a slaughterhouse (Haimen goat Research Center; Haimen, Nantong, China), delivered to the laboratory within 3-4 h and washed with normal saline. The connective tissues and the attached oviducts were removed. The ovaries were transferred into Petri dishes and the 2-6 $\mathrm{mm}$ follicles were sectioned. Cumulus-oocyte complexes (COCs) appropriate for IVM were selected for IVM culture. The base medium for IVM comprised modified TCM199 supplemented with $10 \mu \mathrm{g} / \mathrm{ml}$ follicle-stimulating hormone luteinizing hormone, estrogen (all Sigma-Aldrich) and 10\% FBS. This media was further supplemented with $100 \mu \mathrm{M}$ cysteine and $100 \mu \mathrm{M}$ cystine or $100 \mu \mathrm{M} \mathrm{H}_{2} \mathrm{O}_{2}$, according to the experimental design. The selected COCs were cultured for $20-22 \mathrm{~h}$ at $38.5^{\circ} \mathrm{C}$ under a saturated $5 \% \mathrm{CO}_{2}$ atmosphere.

Oocyte recovery. Following IVM, the COCs were treated with $0.1 \%$ hyaluronidase to strip their cumulus cells by repeated pipetting through a narrow-bore pipette in culture media. Good-quality MII oocytes with a uniform cytoplasm and a well-extruded polar body were selected to assess for parthenogenetic activation.

In vitro culture. The parthenogenetic embryos were treated with TCM 199 containing $5 \mu \mathrm{M}$ ionomycin for $5 \mathrm{~min}$, incubated in TCM 199 containing 2 mM 6-DMAP for $4 \mathrm{~h}$, and washed three times in $100 \mu \mathrm{l}$ of M16 medium. The oocytes were then transferred into $100 \mu 1 \mathrm{M} 16$ droplets under mineral oil and cultured for 6 days at $38.5^{\circ} \mathrm{C}$ under $5 \% \mathrm{CO}_{2}$. Cleavage and development to the blastocyst stage were observed on day 2.5 (day of parthenogenetic activation=day 0.5 ) and day 6.5 , respectively. Blastocysts, which developed on day 6.5 , were fixed to examine their cell numbers. The total number of blastocysts were determined under a Nikon Eclipse TE2000 fluorescence microscope (Nikon Corporation, Tokyo, Japan) following Hoechst 33342 staining (Sigma-Aldrich; cat. no. B-2261).

Reverse transcription-quantitative polymerase chain reaction (RT-qPCR) analysis. Mature oocytes (30 oocytes per group) were collected to analyze the expression levels of genes associated with the mitochondria and apoptosis in goat oocytes. Total mRNA was extracted using the RNeasy ${ }^{\circledR}$ Micro kit, according to the manufacturer's protocol. For the RT, total mRNA with a final volume of $20 \mu \mathrm{l}$ (containing $0.5 \mathrm{mg}$ oligo-dT, 1X RT buffer, $10 \mathrm{mM}$ dithiothreitol and $10 \mathrm{mM}$ dNTP) was reverse transcribed at $37^{\circ} \mathrm{C}$ for $50 \mathrm{~min}$ and at $70^{\circ} \mathrm{C}$ for $15 \mathrm{~min}$, and the products were stored at $4^{\circ} \mathrm{C}$ until use. The qPCR was performed using an $\mathrm{qPCR}$ reagent kit with gDNA Eraser. The total reaction volume of $20 \mu \mathrm{l}$ contained $2 \mu \mathrm{l}$ of $5 \mathrm{X}$ gDNA Eraser Buffer, $1 \mu \mathrm{l}$ of gDNA Eraser, $1 \mu \mathrm{g}$ of total RNA, $4 \mu \mathrm{l}$ of $5 \mathrm{X}$ RT Buffer, $1 \mu \mathrm{l}$ of qPCR enzyme mix, $1 \mu \mathrm{l}$ of RT Primer Mix, and sufficient nuclease-free $\mathrm{H}_{2} \mathrm{O}$. The qPCR was performed at $42^{\circ} \mathrm{C}$ for $2 \mathrm{~min}, 37^{\circ} \mathrm{C}$ for $15 \mathrm{~min}$, followed by a denaturation step at $85^{\circ} \mathrm{C}$ for $15 \mathrm{sec}$ and cooling on ice. The primer sequences for each gene are shown in Table I. The tests were performed in triplicate, and the mRNA levels in each sample were normalized to the mRNA level of GAPDH.

Analysis of gene expression levels using qPCR. All transcripts were quantified by qPCR using an ABI 7300 PRISM system (Applied Biosystems; Thermo Fisher Scientific, Inc.). The amplification products of PGC-1 $\alpha$, NRF-1, BAX, Bcl-2 and GAPDH were detected using SYBR green staining. The GenBank accession numbers and primer sequences used to amplify the target genes are presented in Table I.

The qPCRs were run in triplicate in a total volume of $20 \mu 1$, consisting of SYBR Premix Ex Taq, ROX Reference Dye, $200 \mathrm{nM}$ of each gene-specific primer and $100 \mathrm{ng}$ equivalent cDNA. The amplification conditions were as follows: DNA polymerase activation at $95^{\circ} \mathrm{C}$ for $30 \mathrm{sec}$, followed by 
Table I. Primers used for reverse transcription-quantitative polymerase chain reaction analysis.

\begin{tabular}{|c|c|c|c|}
\hline $\begin{array}{l}\text { Gene and reference sequence } \\
\text { (GenBank accession no.) }\end{array}$ & $\begin{array}{l}\text { Amplicon primer } \\
\text { sequence }\end{array}$ & $\begin{array}{l}\text { Annealing } \\
\text { size (bp) }\end{array}$ & Temperature $\left({ }^{\circ} \mathrm{C}\right)$ \\
\hline NRF-1 (AY368269) & $\begin{array}{l}\text { F: 5'-AGGCTGGGGCAAAGAAAG-3' } \\
\text { R: 5'-CCAACCTGGATAAGCGAGAC-3' }\end{array}$ & 303 & 58.0 \\
\hline PGC-1 $\alpha(A Y 321517)$ & $\begin{array}{l}\text { F: 5'-CACCCACAACTCCTCCTCAT-3' } \\
\text { R: 5'-GCCTTCCTTTCCTCGTGTC-3' }\end{array}$ & 232 & 58.0 \\
\hline BAX (XM_002701934.1) & $\begin{array}{l}\text { F: 5'-GCATCCACCAAGAAGCTGAG-3' } \\
\text { R: 5'-CCGCCACTCGGAAAAAGAC-3' }\end{array}$ & 130 & 58.0 \\
\hline BCL2 (NM_001166486.1) & $\begin{array}{l}\text { F: 5'-ATGTGTGTGGAGAGCGTCA-3' } \\
\text { R: 5'-AGAGACAGCCAGGAGAAATC-3' }\end{array}$ & 182 & 58.0 \\
\hline GAPDH (NM001034034) & $\begin{array}{l}\text { F: 5'-CGACTTCAACAGCGACACTCAC-3' } \\
\text { R: 5'-CCCTGTTGCTGTAGCCAAATTC-3' }\end{array}$ & 118 & 58.0 \\
\hline
\end{tabular}

NRF-1, nuclear respiratory factor-1; PGC-1 $\alpha$, proliferator-activated receptor $\gamma$ coactivator-1 $\alpha$; BCL2, B cell lymphoma 2; BAX, Bcl-2-associated X protein; F, forward; R, reverse.

40 amplification cycles of $95^{\circ} \mathrm{C}$ for $5 \mathrm{sec}$ and $58^{\circ} \mathrm{C}$ for $31 \mathrm{sec}$. At the end of the amplification cycles, melting curve analysis was performed to verify gene-specific amplification. The comparative CQ method (17) was used to quantify the relative expression levels of the target genes. For ease of comparison, the average expression level of each gene from the control group was set as one (16).

Terminal deoxynucleotidyl transferase UTP nick end labeling (TUNEL) assay. The TUNEL method was performed using a One-Step TUNEL Apoptosis Assay kit, as previously described. Briefly, the control and experimental oocytes (20 oocytes per group) undergoing shrinkage were fixed in $3.7 \%$ formaldehyde in PBS for $1 \mathrm{~h}$ at $18-20^{\circ} \mathrm{C}$. Following fixation, the oocytes were washed in PBS and permeabilized by incubation in $0.1 \%(\mathrm{v} / \mathrm{v})$ Triton $\mathrm{X}-100$ for $2 \mathrm{~min}$ at $4^{\circ} \mathrm{C}$. The oocytes were then washed twice in PBS and incubated with the TUNEL labeling media in the dark for $1 \mathrm{~h}$ at $37^{\circ} \mathrm{C}$. Following counterstaining with $10 \mu \mathrm{g} / \mathrm{ml}$ Hoechst 33342 for $10 \mathrm{~min}$ at $37^{\circ} \mathrm{C}$ to label all the nuclei, the oocytes were mounted with light coverslip compression and observed under a microscope.

GSH and oxidized glutathione (GSSG) assay. The GSH concentrations were measured in oocytes matured in vitro under four IVM culture conditions, according to the GSH and GSSG Assay kit. The oocytes (30 oocytes per group) were carefully denuded by repeated pipetting in $0.1 \%(\mathrm{w} / \mathrm{v})$ hyaluronidase (Sigma-Aldrich) and washed several times in polyvinyl alcohol-PBS to remove any trace of materials with thiol groups. The oocytes were stored in a microtube at $-20^{\circ} \mathrm{C}$ until they were assayed (30 oocytes per tube). All procedures complied with the manufacturer's protocol. Briefly, GSH was assayed using 5,5-dithio-bis (2-nitrobenzoic) acid (DTNB)-GSSG reductase recycling. The GSSG was measured by measuring the 5-thio-2-nitrobenzoic acid (TNB) produced from the reaction of reduced GSH with DTNB. The rate of TNB formation was measured at $412 \mathrm{~nm}$ using a Multiskan ${ }^{\mathrm{TM}}$
FC Microplate Photometer (Thermo Fisher Scientific, Inc.), over $3 \mathrm{~min}$. The reduced GSH concentration in the sample was calculated by subtracting the GSSG from GSH.

Caspase-3 activity assay. Caspase-3 activity was analyzed in the control and experimental oocytes using a Caspase-3 Activity kit, with Ac-DEVD-pNA as the colorimetrically-specific substrate. Briefly, 30 oocytes from each group were washed twice in PBS and then lysed in $100 \mu \mathrm{l}$ of chilled lysis buffer (Gibco) at $4^{\circ} \mathrm{C}$ for $10 \mathrm{~min}$. The lysate was centrifuged at $20,000 \mathrm{x} \mathrm{g}$ at $4^{\circ} \mathrm{C}$ for $10 \mathrm{~min}$, and the supernatant was incubated for $7 \mathrm{~h}$ at $37^{\circ} \mathrm{C}$ with $10 \mu \mathrm{l}$ of caspase- 3 substrate. Substrate cleavage was measured using an Hitachi Fluorescence Spectrophotometer F-7000 (Hitachi, Ltd., Tokyo, Japan) at $405 \mathrm{~nm}$ and was corrected to the protein content in the lysate. The caspase- 3 activity is presented as the fold increase in optical density/30 oocytes.

Statistical analysis. Data are expressed as the mean \pm standard error of the mean of triplicate samples. All percentages were subjected to arcsine square root transformation prior to statistical analysis. The data were analyzed using either Student's $t$-test or one-way analysis of variance followed by a multiple $t$-test. All statistical analysis was performed using SPSS (version 17.0; SPSS, Inc. Chicago, IL, USA). P<0.05 was considered to indicate a statistically significant difference.

\section{Results}

Optimal concentrations of $\mathrm{H}_{2} \mathrm{O}_{2}$ and $\mathrm{CC}$ for oxidative stress and goat parthenogenetic embryonic development. $\mathrm{H}_{2} \mathrm{O}_{2}$ induces ROS generation, causing oxidative stress. CC is usually used to improve GSH synthesis, as GSH protects cells against the destructive effects of ROS. To determine the optimal concentrations of $\mathrm{H}_{2} \mathrm{O}_{2}$ and $\mathrm{CC}$, the present study evaluated goat oocyte maturation rate and parthenogenesis blastocyst formation rate. The oocytes treated with $100 \mu \mathrm{MH}_{2} \mathrm{O}_{2}$ exhibited significantly decreased maturation rates and blastocyst rates, 
Table II. Effect of oxidative stress on goat oocyte development following parthenogenetic activation.

\begin{tabular}{|c|c|c|c|c|c|}
\hline Treatment & $\begin{array}{c}\text { Oocytes } \\
\text { examined }(n)\end{array}$ & Maturation rate & Cleavage rate & $\begin{array}{l}\text { Blastocyst } \\
\text { formation rate }\end{array}$ & $\begin{array}{c}\text { Cells/ } \\
\text { blastocysts (n) }\end{array}$ \\
\hline Control & 768 & $509(65.71 \pm 2.74)^{\mathrm{a}}$ & $321(62.37 \pm 1.16)^{\mathrm{a}}$ & $67(20.57 \pm 0.61)^{\mathrm{a}}$ & $92 \pm 2.1^{\mathrm{a}}$ \\
\hline $\mathrm{H}_{2} \mathrm{O}_{2}$ & 854 & $464(49.47 \pm 2.65)^{\mathrm{b}}$ & $255(65.86 \pm 4.69)^{\mathrm{a}}$ & $35(13.47 \pm 1.11)^{\mathrm{b}}$ & $75 \pm 3.6^{b}$ \\
\hline $\mathrm{CC}$ & 1024 & $786(78.36 \pm 2.83)^{c}$ & $500(66.82 \pm 4.52)^{\mathrm{a}}$ & $113(23.06 \pm 0.59)^{\mathrm{a}}$ & $99 \pm 3.4^{\mathrm{a}}$ \\
\hline $\mathrm{H}_{2} \mathrm{O}_{2}+\mathrm{CC}$ & 760 & $524(69.96 \pm 3.51)^{\mathrm{a}}$ & $317(62.88 \pm 1.90)^{\mathrm{a}}$ & $63(19.19 \pm 0.53)^{\mathrm{a}}$ & $90 \pm 2.7^{\mathrm{a}}$ \\
\hline
\end{tabular}

Data in brackets are the mean percentage \pm standard error of the mean. Data not in brackets indicate the number of oocytes or embryos. Superscript letters are statistically different $(\mathrm{P}<0.05)$; ${ }^{a} \mathrm{P}<0.05$ vs. control group; ${ }^{b} \mathrm{P}<0.05$ vs. control group, $\mathrm{CC}$ group and $\mathrm{H}_{2} \mathrm{O}_{2}+\mathrm{CC}$ group; ${ }^{c} \mathrm{P}<0.05$ vs. control group, $\mathrm{H}_{2} \mathrm{O}_{2}$ group and $\mathrm{H}_{2} \mathrm{O}_{2}+\mathrm{CC}$ group. $\mathrm{H}_{2} \mathrm{O}_{2}$, hydrogen peroxide; $\mathrm{CC}$ cystine and cysteine.
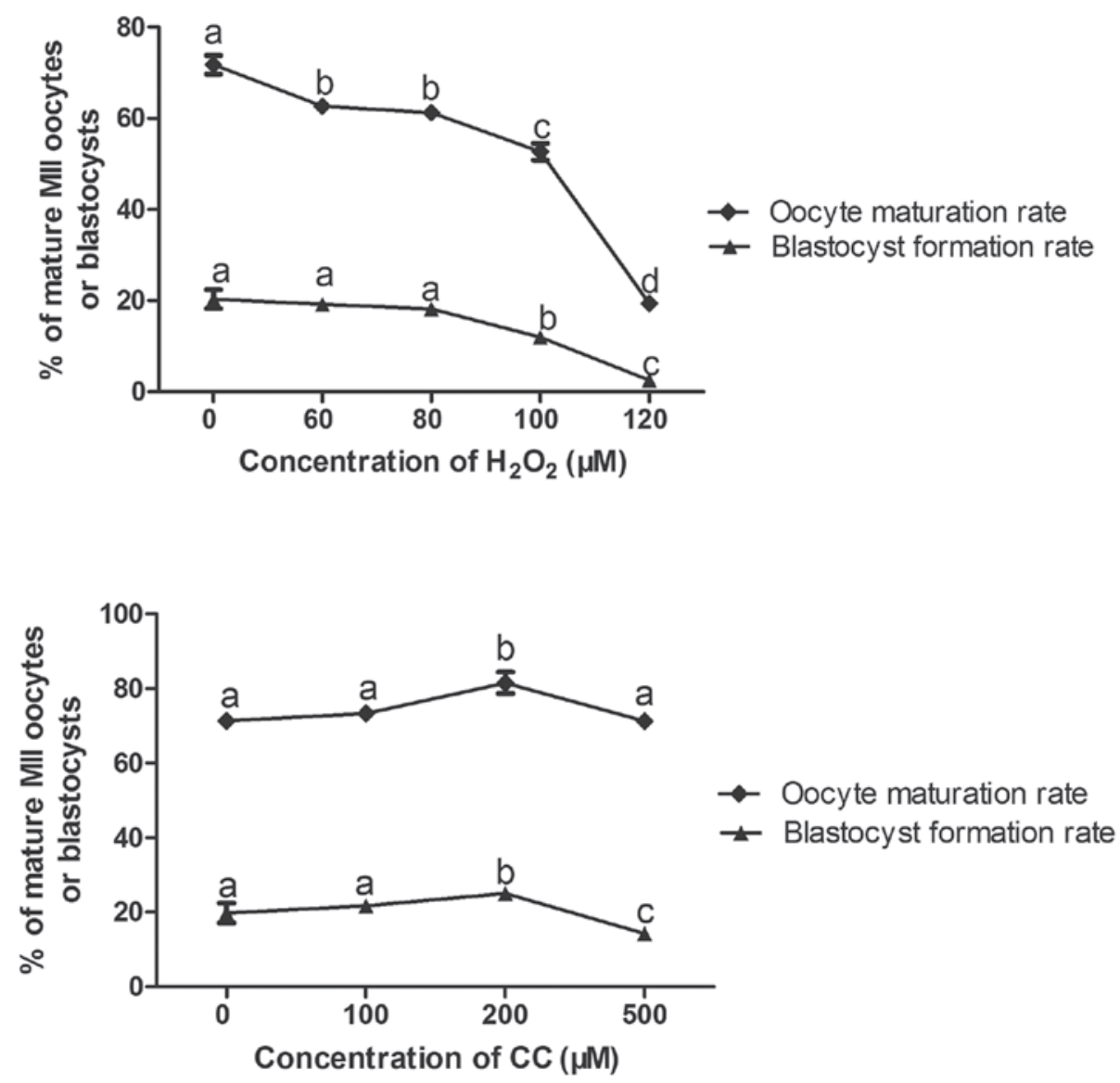

Figure 1. Optimal concentrations of $\mathrm{H}_{2} \mathrm{O}_{2}$ and $\mathrm{CC}$ and the parthenogenetic development of embryos. Data are expressed as the mean \pm standard error of the mean Means with different superscript letters are statistically different $(\mathrm{P}<0.05)$. Oocyte maturation rate: ${ }^{\mathrm{a}} \mathrm{P}<0.05$ vs. group 0 ; ${ }^{\text {b }} \mathrm{P}<0.05$ vs. group $0,100 \mu \mathrm{m}$ and $120 \mu \mathrm{m} ;{ }^{\mathrm{C}} \mathrm{P}<0.05 \mathrm{vs}$. group $0,60 \mu \mathrm{m}, 80 \mu \mathrm{m}$ and $120 \mu \mathrm{m} ;{ }^{\mathrm{d}} \mathrm{P}<0.05$ vs. group $0,60 \mu \mathrm{m}, 80 \mu \mathrm{m}, 100 \mu \mathrm{m}$ and $120 \mu \mathrm{m}$. Blastocyst formation rate: ${ }^{\mathrm{a}} \mathrm{P}<0.05 \mathrm{vs}$. group $0 ;{ }^{b} \mathrm{P}<0.05$ vs. group $0,60 \mu \mathrm{m}, 80 \mu \mathrm{m}$ and $120 \mu \mathrm{m} ; \mathrm{c}=\mathrm{P}<0.05$ vs. group $60 \mu \mathrm{m}, 80 \mu \mathrm{m}$ and $100 \mu \mathrm{m}$. For Optimal concentrations of CC: Oocyte maturation rate: ${ }^{\mathrm{P}} \mathrm{P}<0.05$ vs. group $0 ;{ }^{\mathrm{b}} \mathrm{P}<0.05$ vs. group $0,100 \mu \mathrm{m}$ and $500 \mu \mathrm{m}$. Blastocyst formation rate: ${ }^{\mathrm{a}} \mathrm{P}<0.05$ vs. group 0 ; ${ }^{b} \mathrm{P}<0.05 \mathrm{vs}$. group $0,100 \mu \mathrm{m}$ and $500 \mu \mathrm{m}$; ${ }^{\mathrm{c}} \mathrm{P}<0.05$ vs. group $0,100 \mu \mathrm{m}$ and $200 \mu \mathrm{m} . \mathrm{H}_{2} \mathrm{O}_{2}$, hydrogen peroxide; $\mathrm{CC}$ cystine and cysteine.

compared with the control group (52.67 \pm 1.81 , vs. $71.78 \pm 2.06$ and $11.98 \pm 1.27$, vs. $20.29 \pm 2.06$, respectively; P<0.05; Fig. 1). However, oocytes treated with $120 \mu \mathrm{M} \mathrm{H}_{2} \mathrm{O}_{2}$ exhibited marked decrease in oocyte maturation rates and blastocyst formation rates $(19.34 \pm 1.43$ and $2.49 \pm 1.36$, respectively), and the high concentration of $\mathrm{H}_{2} \mathrm{O}_{2}$ resulted in a low survival rate of oocytes and thus, the remaining surviving oocytes were insubstantial for the completion of subsequent experiments. Thus, $100 \mu \mathrm{M}$ $\mathrm{H}_{2} \mathrm{O}_{2}$ was considered the optimal concentration for oxidative stress. In addition, when $200 \mu \mathrm{M}$ cysteine and $200 \mu \mathrm{M}$ cystine were added to the IVM media, the oocyte maturation rate and blastocyst formation rate were higher, compared with those the control group $(81.57 \pm 2.86$, vs. $71.41 \pm 1.11 \%$ and $25.04 \pm 1.34$, vs. $19.80 \pm 2.66 \%$, respectively; $\mathrm{P}<0.05)$.

Effect of oxidative stress on goat oocyte development following parthenogenesis. Culturing the goat oocytes in M199 with $\mathrm{H}_{2} \mathrm{O}_{2}$ decreased the oocyte maturation rate and 


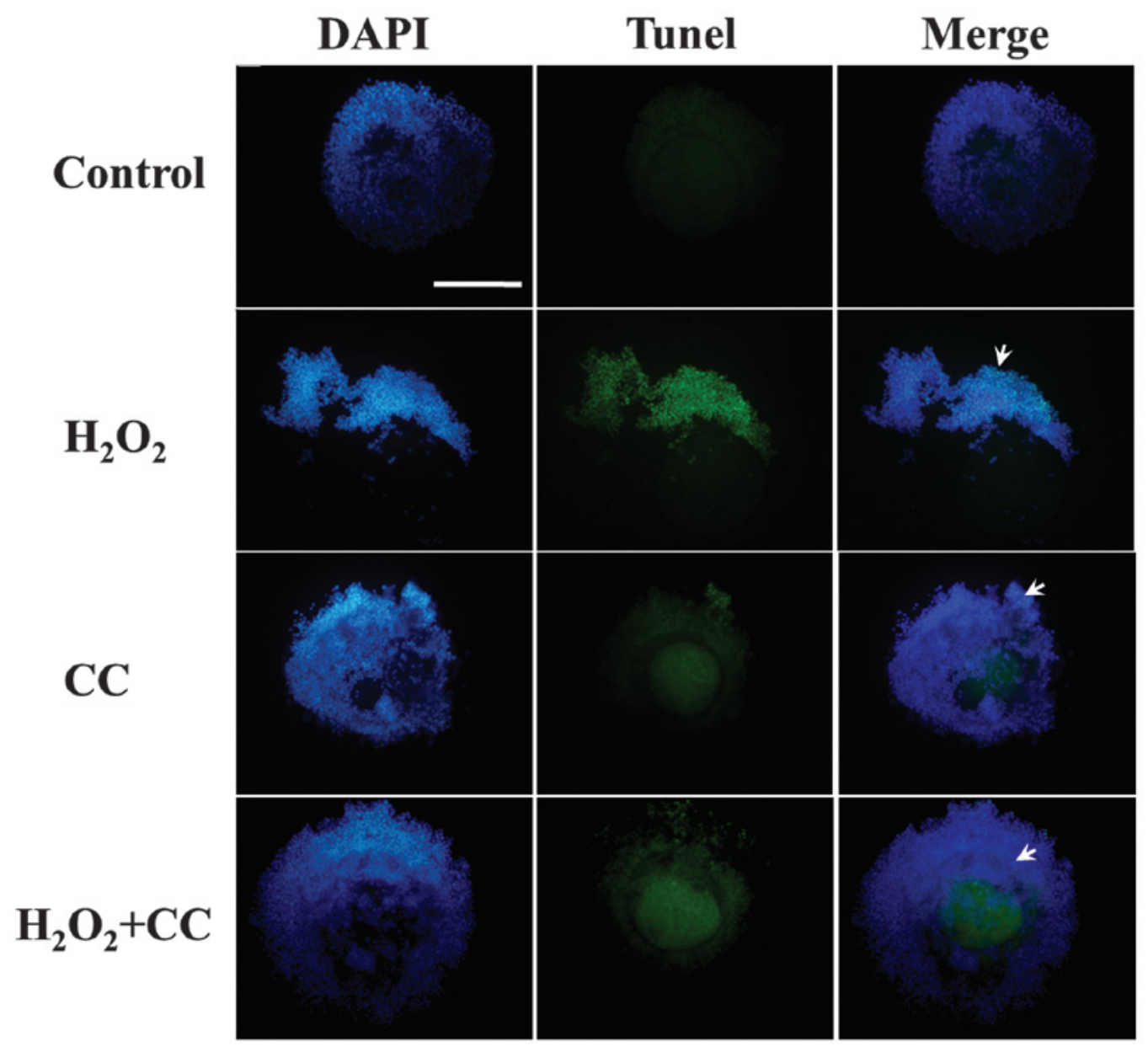

Figure 2. Representative images of the TUNEL assays of goat cumulus-oocyte complexes. The white arrowhead indicates a TUNEL-positive cumulus cell. Apoptosis occurred primarily in the cumulus cells. Blue color, DAPI-stained nuclei; green color, TUNEL-positive cells. The white arrowhead indicates a TUNEL-positive cumulus cell. The control group showed no green color; however, in the $\mathrm{H}_{2} \mathrm{O}_{2}$ group, strong immunostaining is visible primarily in the cumulus cells. The CC group also showed some positive fluorescence. In $\mathrm{H}_{2} \mathrm{O}_{2}+\mathrm{CC}$ group, the TUNEL-positive signal is reduced compared with that in the $\mathrm{H}_{2} \mathrm{O}_{2}$ group. Blue color: DAPI-stained nuclei. Green color: TUNEL-positive cells. Scale bar=100 $\mu \mathrm{m}$. TUNEL, terminal deoxynucleotidyl transferase UTP nick end labeling; $\mathrm{H}_{2} \mathrm{O}_{2}$, hydrogen peroxide; $\mathrm{CC}$ cystine and cysteine.

blastocyst formation rate, compared with the control group $(49.47 \pm 2.65 \%$ vs. $65.71 \pm 2.74$ and $13.47 \pm 1.11$ vs. $20.57 \pm 0.61 \%$ respectively; $\mathrm{P}<0.05$; Table II). The oocyte maturation and blastocyst formation rates in the $\mathrm{CC}+\mathrm{H}_{2} \mathrm{O}_{2}$ group were higher, compared with those in the $\mathrm{H}_{2} \mathrm{O}_{2}$ group $(69.96 \pm 3.51$, vs $49.47 \pm 2.65 \%$ and $19.19 \pm 0.53$, vs. $13.47 \pm 1.11 \%$, respectively; $\mathrm{P}<0.05)$. The oocyte maturation rate and the blastocyst rate in the CC group were also higher, compared with those in the $\mathrm{H}_{2} \mathrm{O}_{2}$ group $(78.36 \pm 2.83$, vs. $49.47 \pm 2.65 \%$ and $23.06 \pm 0.59$, vs $13.47 \pm 1.11 \%$, respectively; $\mathrm{P}<0.05$ ). Furthermore, the mean number of cells per blastocyst in the $\mathrm{H}_{2} \mathrm{O}_{2}$ group was significantly lower, compared with those in the other three groups $(\mathrm{P}<0.05)$, although the embryonic cleavage rates did not differ among the four groups $(\mathrm{P}>0.05)$.

Effect of oxidative stress on apoptosis of COCs following maturation. A TUNEL assay was used to evaluate the quality and viability of the goat oocytes cultured in M199 with stress inducers. The goat oocytes treated with $\mathrm{H}_{2} \mathrm{O}_{2}$ exhibited significantly increased DNA fragmentation, compared with the control group $(121 \pm 1.89$ cells/COC, vs. $7.8 \pm 1.32$ cells/COC, respectively; $\mathrm{P}<0.05$ ), as shown in Figs. 2 and $3 \mathrm{~A}$ ). The $\mathrm{H}_{2} \mathrm{O}_{2}$ media containing $\mathrm{CC}$ further reduced the number of apoptotic cells (36 \pm 1.13 cells/COC), similar with the CC group (25 \pm 2.10 cells/COC). These findings indicated that oxidative stress induced apoptosis during goat oocyte IVM.

GSH concentrations of goat oocytes cultured in oxidative maturation media with and without $C C$. The mean intracellular GSH concentrations in the MII oocytes treated with $\mathrm{H}_{2} \mathrm{O}_{2}$ were significantly lower, compared with those in the control groups $(0.31 \pm 0.18$, vs. $3.18 \pm 0.38$ pmol/oocyte; $\mathrm{P}<0.05$; Fig. 3B). The addition of $\mathrm{CC}$ to the media significantly increased the GSH concentrations, compared with the control and $\mathrm{H}_{2} \mathrm{O}_{2}$ groups $(7.53 \pm 0.41$ vs. $0.31 \pm 0.18$ and $3.18 \pm 0.38 \mathrm{pmol} /$ oocyte, respectively; $\mathrm{P}<0.05)$. In addition, the GSH concentration of the MII oocytes in the CC group was higher, compared with those of the control and $\mathrm{H}_{2} \mathrm{O}_{2}$ groups $(8.47 \pm 0.46$, vs. $0.31 \pm 0.18$ and $3.18 \pm 0.38$ pmol/oocyte, respectively; $\mathrm{P}<0.05)$.

Activity of caspase-3 activity in goat oocytes cultured in oxidative maturation media with and without $C C$. To confirm whether caspase-3 is involved in the IVM of goat 
A

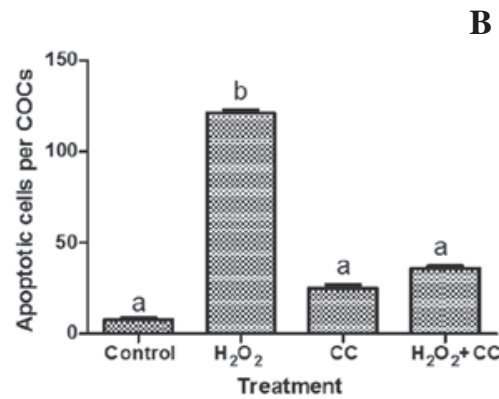

B

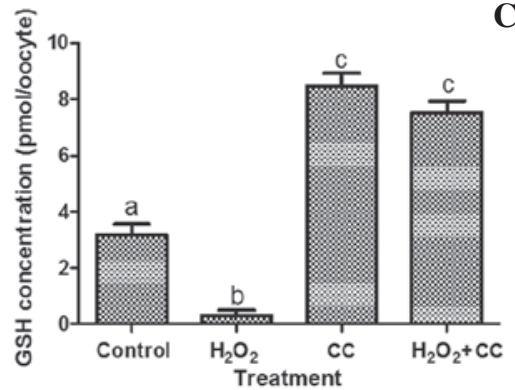

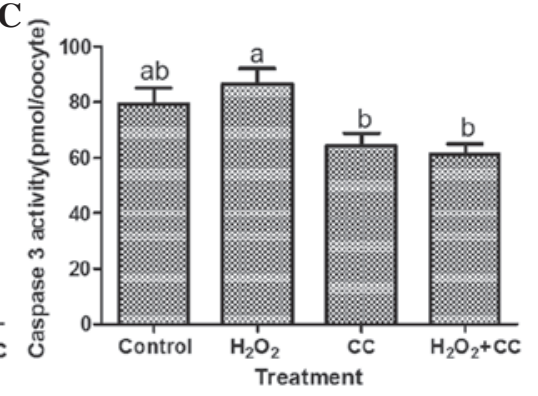

Figure 3. Effects of oxidative stress on levels of apoptosis, intracellular GSH concentrations and caspase-3 activity in goat oocytes following maturation. (A) Number of TUNEL-positive cells in goat cumulus-oocyte complexes, presented as the number of TUNEL-positive nuclei. (B) Intracellular GSH concentrations in the goat oocytes. (C) Caspase-3 activity in the goat oocytes. Data are expressed as the mean \pm standard error of the mean. Means with different superscript letters are statistically different $(\mathrm{P}<0.05)$. In (A) ${ }^{a} \mathrm{P}<0.05$ vs. control group; $\mathrm{b}=\mathrm{P}<0.05$ vs. control group, $\mathrm{CC}$ group, and $\mathrm{H}_{2} \mathrm{O}_{2}+\mathrm{CC}$ group. In (B) ${ }^{a} \mathrm{P}<0.05$ vs. control group; ${ }^{b} \mathrm{P}<0.05$ vs. control group, $\mathrm{CC}$ group, and $\mathrm{H}_{2} \mathrm{O}_{2}+\mathrm{CC}$ group; ${ }^{\mathrm{c}} \mathrm{P}<0.05$ vs. control group and $\mathrm{H}_{2} \mathrm{O}_{2}$ group. In $(\mathrm{C})^{\mathrm{a}, \mathrm{b}} \mathrm{P}<0.05$ vs. $\mathrm{H}_{2} \mathrm{O}_{2}$ group. GSH, glutathione; TUNEL, terminal deoxynucleotidyl transferase UTP nick end labeling; $\mathrm{H}_{2} \mathrm{O}_{2}$, hydrogen peroxide.

\section{PGC-1 $\alpha$}

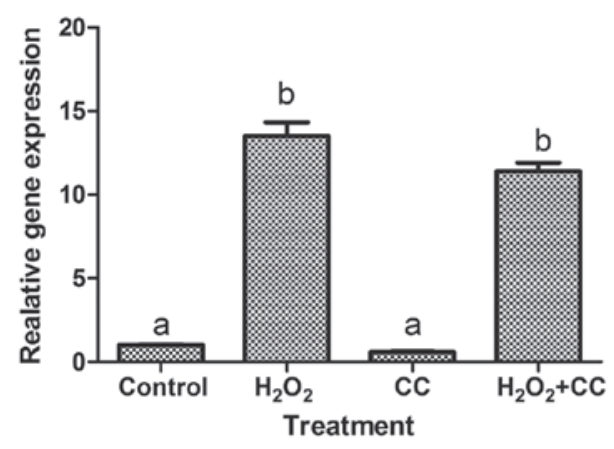

BAX

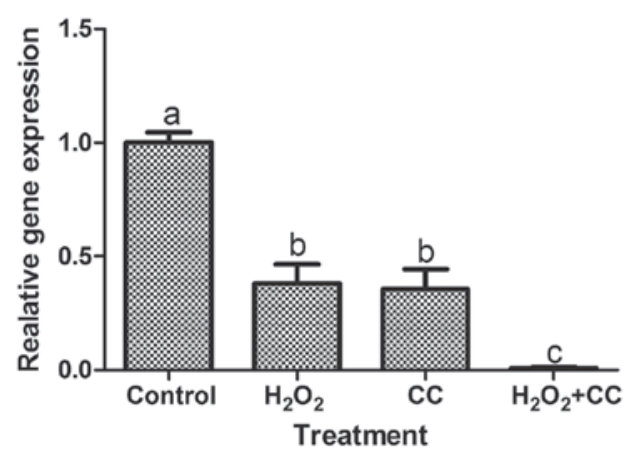

NRF-1

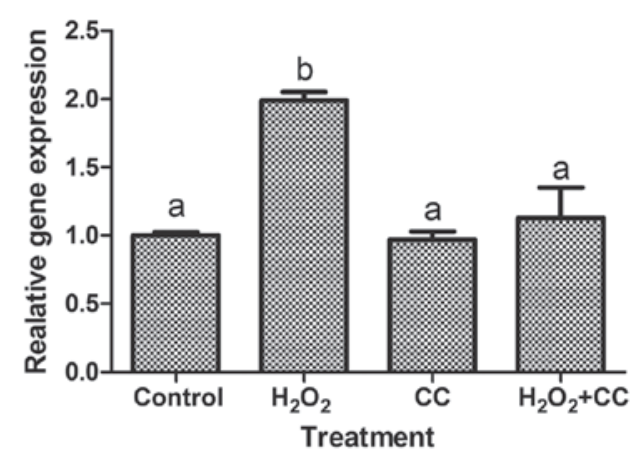

Bcl-2

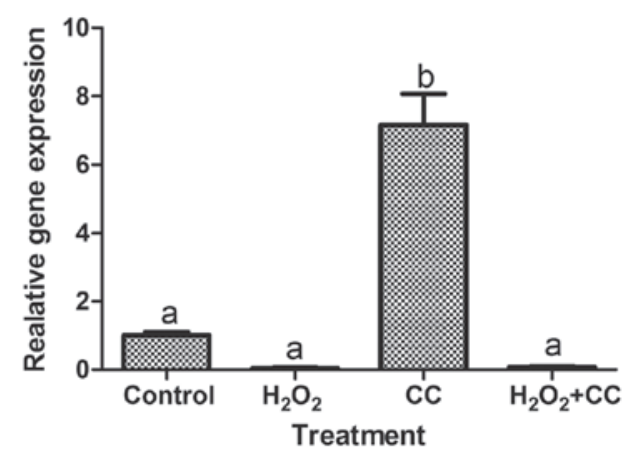

BAX:BCL-2

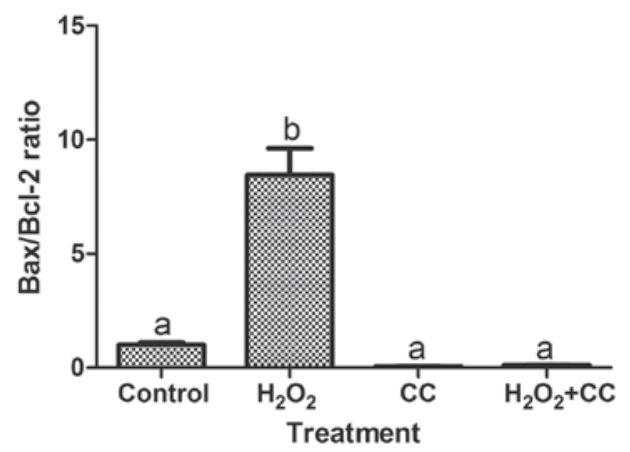

Figure 4. Gene expression levels in goat oocytes, determined using reverese transcription-quantitative polymerase chain reaction analysis. Data are presented as the mean \pm standard error of the mean. Means with different superscript letters are statistically different $(\mathrm{P}<0.05)$. For $\mathrm{PGC}-1$, ${ }^{\mathrm{a}} \mathrm{P}<0.05$ vs. group control; ${ }^{b} \mathrm{P}<0.05$ vs. group control and group CC. NRF-1, ${ }^{\mathrm{a}} \mathrm{P}<0.05$ vs. control group; ${ }^{\mathrm{b}} \mathrm{P}<0.05$ vs. control group, $\mathrm{CC}$ group and $\mathrm{H}_{2} \mathrm{O}_{2}+\mathrm{CC}$ group. $\mathrm{BAX}$, ${ }^{\mathrm{a}} \mathrm{P}<0.05$ vs. control group; ${ }^{b} \mathrm{P}<0.05$ vs. control group and $\mathrm{H}_{2} \mathrm{O}_{2}+\mathrm{CC}$ group, ${ }^{c} \mathrm{P}<0.05$ vs. control group, $\mathrm{H}_{2} \mathrm{O}_{2}$ group and $\mathrm{CC}$ group. $\mathrm{Bcl}-2,{ }^{\mathrm{a}} \mathrm{P}<0.05$ vs. control group; ${ }^{\text {b }} \mathrm{P}<0.05$ vs. control group, $\mathrm{H}_{2} \mathrm{O}_{2}$ group, and group $\mathrm{H}_{2} \mathrm{O}_{2}+\mathrm{CC}$. BAX:Bcl-2, ${ }^{a} \mathrm{P}<0.05$ vs. control group; ${ }^{b} \mathrm{P}<0.05$ vs. control group, $\mathrm{CC}$ group and $\mathrm{H}_{2} \mathrm{O}_{2}+\mathrm{CC}$ group. $\mathrm{H}_{2} \mathrm{O}_{2}$, hydrogen peroxide; CC, cystine and cysteine; PGC-1 $\alpha$, proliferator-activated receptor $\gamma$ coactivator-1 $\alpha$, NRF-1, nuclear respiratory factor-1; Bcl-2, B cell lymphoma 2; BAX, Bcl-2 -associated X factor. 
oocytes in $\mathrm{H}_{2} \mathrm{O}_{2}$-induced oxidative media, caspase- 3 activity was measured using its specific substrate, Ac-DEVD-MCA. The activity of caspase- 3 in the MII oocytes with $\mathrm{H}_{2} \mathrm{O}_{2}$ was $86.4 \pm 5.71 \mathrm{pmol} /$ oocyte, which was significantly higher than the caspase- 3 activities of the oocytes in the $\mathrm{CC}$ group and the $\mathrm{H}_{2} \mathrm{O}_{2}+\mathrm{CC}$ group $(64.3 \pm 4.54$ and $15 \pm 2.46$ pmol/oocyte, respectively; $\mathrm{P}<0.05$; Fig. $3 \mathrm{C})$.

Gene expression in goat oocytes cultured in oxidative maturation media with and without $C C$. The expression levels of selected genes were determined in MII oocytes during IVM, following treatment with $\mathrm{H}_{2} \mathrm{O}_{2}$ and. or CC. The transcription levels were highly variable in all treatment groups. A comparable pattern of mRNA expression was observed for all transcripts analyzed, although certain differences were noted (Fig. 4). The expression levels of PGC- $1 \alpha$ and NRF-1 were significantly higher in the $\mathrm{H}_{2} \mathrm{O}_{2}$ group, compared with the control group $(\mathrm{P}<0.05)$. Adding $\mathrm{CC}$ to the oxidative media significantly downregulated the expression of PGC-1 $\alpha$ and the expression of NRF-1 $(\mathrm{P}<0.05)$. The gene transcription levels of BAX were significantly lower in the $\mathrm{H}_{2} \mathrm{O}_{2}$ group, compared with the control group $(\mathrm{P}<0.05)$. The gene expression of BCL-2 in the oocytes of the CC group was upregulated, compared with the other three groups $(\mathrm{P}<0.05)$. Furthermore, the $\mathrm{BAX}$ :BCL-2 ratio in the $\mathrm{H}_{2} \mathrm{O}_{2}$ group was higher, compared with the other three groups $(\mathrm{P}<0.05)$.

\section{Discussion}

Mammalian embryonic development in vitro is affected by culture conditions. In particular, ROS are predominantly generated from the environment surrounding embryos. Therefore, several studies have attempted to reduce levels of oxidative stress, which causes defects in embryonic development. The present study demonstrated that the oocytes exposed to $200 \mu \mathrm{M}$ cysteine and $200 \mu \mathrm{M}$ cystine exhibited improved developed, compared with the oocytes in the other treatment groups. By contrast, increasing the concentrations of cysteine and cystine to $500 \mu \mathrm{M}$ significantly decreased blastocyst formation. This result indicated that higher concentrations of cysteine and cystine do not improve embryonic development, possibly due to high cystine concentrations disrupting the redox equilibrium in cells (18). However, a previous bovine study suggested that adding $1.2 \mathrm{mM}$ of cysteine to IVM media inhibits the production of ROS in oocytes and the apoptosis of cumulus cells (19). Different culture media, and the combination of cysteine and cystine may affect the concentrations used. Salmen et al confirmed that supplementing cysteine to oocyte culture media increases the intracellular concentration of GSH in oocytes, and promotes pronuclear formation and embryonic development in mice (20). Yoshida et al found that adding cysteine to the maturation medium of pig oocytes increases GSH synthesis, producing GSH concentrations comparable to those found in oocytes matured in vivo (21). These data suggest that culturing early embryos in vitro with cysteine and cystine provides more suitable conditions for embryonic growth and development. In the present study, $100 \mu \mathrm{M} \mathrm{H}_{2} \mathrm{O}_{2}$ was used to induce oocyte oxidative stress. Adding cysteine and cystine to the oocytes under oxidative conditions improved oocyte maturation and the parthenogenesis of embryonic development, and also demonstrated that the addition of cysteine and cystine at appropriate concentrations during oocyte in vitro culture reduced oxygen tension and improved blastocyst development.

Cysteine, is arises in mammals through the metabolism of pantetheine, a component of coenzyme A (22). Cystine is essential for GSH synthesis, and it directly increases the GSH content of cells and tissues. The GSH content is increased through increased synthesis by adaptive mechanisms to oxidative stress. However, severe oxidative stress suppresses GSH levels through deactivation of these adaptive mechanisms (23). GSH functions as an antioxidant through two mechanisms: i) it functions as an ROS scavenger by reacting with certain species; and ii) it acts as an inhibitor of transcription factor nuclear factor- $\kappa \mathrm{B}$ activation, thereby controlling the synthesis of various enzymes $(24,25)$. Acute increases in levels of oxidative stress in cells significantly increases cellular apoptosis, which can be attenuated by pretreatment with GSH-ethyl ester (26). In the present study, supplementation with cysteine and cystine under oxidative conditions decreased the number of apoptotic cells and decreased caspase- 3 activity, which suggested that increasing GSH prevented apoptosis of the goat oocytes. Kizhakkayil et al further demonstrated that GSH depletion induces caspase-dependent and caspase-independent apoptosis in human leukemic cells (27).

The mitochondria reportedly have anti-apoptotic and antioxidant functions in germ cells and granulosa cells $(28,29)$. The mitochondrial regulators, NRF-1 and PGC- $1 \alpha$, interact to regulate oxidative metabolism $(30,31)$. By contrast, endotoxin-induced oxidative stress causes the mitochondrial translocation of the pro-apoptotic protein, Bax, increases the total expression of Bax and downregulates the expression of the antiapoptotic protein, BCL-2 (32). In the present study, PGC-1 $\alpha$ and NRF-1 were expressed at higher levels under oxidative conditions, compared with the other groups, possibly due to the oocytes requiring mitochondrial biogenesis and a high metabolism when exposed to oxidative stress (33). In addition, the BAX/BCL-2 ratio was highest in the oxidative stress group, which suggested that the mitochondrial pathway may be involved in the apoptosis mediated by $\mathrm{H}_{2} \mathrm{O}_{2}$-induced oxidative stress (34).

In conclusion, the results of the present study suggested that the addition of appropriate concentrations of cysteine and cystine reduces the oxygen tension triggered by $\mathrm{H}_{2} \mathrm{O}_{2}$ and improves parthenogenetic blastocyst development. Apoptosis is involved in this process via the mitochondrial pathway. These results may improve current understanding of the apoptotic mechanisms involved in oxidative stress, and provide novel insights into optimizing embryonic in vitro development systems.

\section{Acknowledgements}

This study was financially supported by the National Nature Science Foundation of China (grant no. 31272443), the National Nature Science Foundation of Jiangsu Province, China (grant no. BK20140541), the Ministry of Science and Technology Support Project of China (grant no. 2011BAD19B02-7) and the Open Research Fund of State Key Laboratory of Bioelectronics, Southeast University, and Jiangsu University Fund (grant no. 1291270022). 


\section{References}

1. Chaube SK, Prasad PV, Thakur SC and Shrivastav TG: Hydrogen peroxide modulates meiotic cell cycle and induces morphological features characteristic of apoptosis in rat oocytes cultured in vitro. Apoptosis 10: 863-874, 2005.

2. Deleuze S and Goudet G: Cysteamine supplementation of in vitro maturation media: A review. Reprod Domest Anim 45: e476-e482, 2010.

3. Tamura H, Takasaki A, Taketani T, Tanabe M, Kizuka F, Lee L, Tamura I, Maekawa R, Aasada H, Yamagata Y and Sugino N: The role of melatonin as an antioxidant in the follicle. J Ovarian Res 5: 5, 2012.

4. Agarwal A, Gupta S and Sharma RK: Role of oxidative stress in female reproduction. Reprod Biol Endocrinol 3: 28, 2005.

5. Goto Y, Noda Y, Mori T and Nakano M: Increased generation of reactive oxygen species in embryos cultured in vitro. Free Radic Biol Med 15: 69-75, 1993.

6. Tamura H, Takasaki A, Miwa I, Taniguchi K, Maekawa R, Asada H, Taketani T, Matsuoka A, Yamagata Y and Shimamura K: Oxidative stress impairs oocyte quality and melatonin protects oocytes from free radical damage and improves fertilization rate. J Pineal Res 44: 280-287, 2008.

7. De Matos DG and Furnus CC: The importance of having high glutathione $(\mathrm{GSH})$ level after bovine in vitro maturation on embryo development effect of beta-mercaptoethanol, cysteine and cystine. Theriogenology 53: 761-771, 2000.

8. Gasparrini B, Boccia L, Marchandise J, Di Palo R, George F, Donnay I and Zicarelli L: Enrichment of in vitro maturation medium for buffalo (Bubalus bubalis) oocytes with thiol compounds: Effects of cystine on glutathione synthesis and embryo development. Theriogenology 65: 275-287, 2006.

9. Adona PR, de Bem TH, Mesquita LG, Rochetti RC and Leal CL: Embryonic development and gene expression in oocytes cultured in vitro in supplemented pre-maturation and maturation media. Reprod Domest Anim 46: e31-e38, 2011.

10. Kobayashi M, Asakuma S and Fukui Y: Blastocyst production by in vitro maturation and development of porcine oocytes in defined media following intracytoplasmic sperm injection. Zygote 15: 93-102, 2007.

11. Rodríguez-González E, López-Bejar M, Mertens MJ and Paramio MT: Effects on in vitro embryo development and intracellular glutathione content of the presence of thiol compounds during maturation of prepubertal goat oocytes. Mol Reprod Dev 65: 446-453, 2003.

12. Zhou P, Wu YG, Li Q, Lan GC, Wang G, Gao D and Tan JH: The interactions between cysteamine, cystine and cumulus cells increase the intracellular glutathione level and developmental capacity of goat cumulus-denuded oocytes. Reproduction 135: 605-611, 2008

13. Tatone C, Amicarelli F, Carbone MC, Monteleone P, Caserta D, Marci R, Artini PG, Piomboni P and Focarelli R: Cellular and molecular aspects of ovarian follicle ageing. Hum Reprod Update 14: 131-142, 2008.

14. Behrman HR, Kodaman PH, Preston SL and Gao S: Oxidative stress and the ovary. J Soc Gynecol Investig 8 (1 Suppl Proceedings): S40-S42, 2001.

15. Agarwal A and Said TM: Role of sperm chromatin abnormalities and DNA damage in male infertility. Hum Reprod Update 9: 331-345, 2003.

16. Zhou Z, Wan Y, Zhang Y, Wang Z, Jia R, Fan Y, Nie H, Ying S, Huang $\mathrm{P}$ and Wang F: Follicular development and expression of nuclear respiratory factor-1 and perox isome proliferator-activated receptor gamma coactivator-1 alpha in ovaries of fetal and neonatal doelings. J Anim Sci 90: 3752-3761, 2012.

17. Livak KJ and Schmittgen TD: Analysis of relative gene expression data using real-time quantitative PCR and the $2-\Delta \Delta \mathrm{Ct}$ method. Methods 25: 402-408, 2001.
18. Arrigo AP: Gene expression and the thiol redox state. Free Radic Biol Med 27: 936-944, 1999.

19. Nabenishi H, Ohta H, Nishimoto T, Morita T, Ashizawa K and Tsuzuki Y: The effects of cysteine addition during in vitro maturation on the developmental competence, ROS, GSH and apoptosis level of bovine oocytes exposed to heat stress. Zygote 20: 249-259, 2012.

20. Salmen JJ, Skufca F, Matt A, Gushansky G, Mason A and Gardiner CS: Role of glutathione in reproductive tract secretions on mouse preimplantation embryo development. Biol Reprod 73: 308-314, 2005.

21. Yoshida M, Ishigaki K, Nagai T, Chikyu M and Pursel VG: Glutathione concentration during maturation and after fertilization in pig oocytes: Relevance to the ability of oocytes to form male pronucleus. Biol Reprod 49: 89-94, 1993.

22. Pitari G, Maurizi G, Flati V, Ursini CL, Spera L, Duprè S and Cavallini D: Enzymatic synthesis of S-aminoethyl-L-cysteine from pantetheine. Biochim Biophys Acta 1116: 27-33, 1992.

23. Grosicka-Maciag E, Kurpios-Piec D, Grzela T, Czeczot H, Skrzycki M, Szumiło M and Rahden-Staron I: Protective effect of N-acetyl-L-cysteine against disulfiram-induced oxidative stress and apoptosis in V79 cells. Toxicol Appl Pharmacol 248: 210-216, 2010 .

24. Zafarullah M, Li WQ, Sylvester J and Ahmad M: Molecular mechanisms of $\mathrm{N}$-acetylcysteine actions. Cell Mol Life Sci 60: 6-20, 2003.

25. Huang Y, Li W and Kong AN: Anti-oxidative stress regulator NF-E2-related factor 2 mediates the adaptive induction of antioxidant and detoxifying enzymes by lipid peroxidation metabolite 4-hydroxynonenal. Cell Biosci 2: 40, 2012.

26. Aggarwal S, Dimitropoulou C, Lu Q, Black SM and Sharma S: Glutathione supplementation attenuates lipopolysaccharide-induced mitochondrial dysfunction and apoptosis in a mouse model of acute lung injury. Front Physiol 3: 161, 2012.

27. Kizhakkayil J, Thayyullathil F, Chathoth S, Hago A, Patel M and Galadari S: Glutathione regulates caspase-dependent ceramide production and curcumin-induced apoptosis in human leukemic cells. Free Radic Biol Med 52: 1854-1864, 2012.

28. Perez GI, Maravei DV, Trbovich AM, Cidlowski JA, Tilly JL and Hughes FM Jr: Identification of potassium-dependent and -independent components of the apoptotic machinery in mouse ovarian germ cells and granulosa cells. Biol Reprod 63: 1358-1369, 2000

29. Tingaud-Sequeira A, Chauvigné F, Lozano J, Agulleiro MJ, Asensio E and Cerdà J: New insights into molecular pathways associated with flatfish ovarian development and atresia revealed by transcriptional analysis. BMC Genomics 10: 434, 2009.

30. Patti ME, Butte AJ, Crunkhorn S, Cusi K, Berria R, Kashyap S, Miyazaki Y, Kohane I, Costello M, Saccone R, et al: Coordinated reduction of genes of oxidative metabolism in humans with insulin resistance and diabetes: Potential role of PGC1 and NRF1. Proc Natl Acad Sci USA 100: 8466-8471, 2003.

31. Ding L, Liang XG, Zhu DY and Lou YJ: Icariin promotes expression of PGC-1alpha, PPARalpha and NRF-1 during cardiomyocyte differentiation of murine embryonic stem cells in vitro. Acta Pharmacol Sin 28: 1541-1549, 2007.

32. Mishra DP and Dhali A: Endotoxin induces luteal cell apoptosis through the mitochondrial pathway. Prostaglandins Other Lipid Mediat 83: 75-88, 2007.

33. Vina J, Gomez-Cabrera MC, Borras C, Froio T, Sanchis-Gomar F, Martinez-Bello VE and Pallardo FV: Mitochondrial biogenesis in exercise and in ageing. Adv Drug Deliv Rev 61: 1369-1374, 2009.

34. Franco R and Cidlowski JA: Apoptosis and glutathione: Beyond an antioxidant. Cell Death Differ 16: 1303-1314, 2009. 